\title{
Comparison of caesarean section rate and maternal complications in elective induction versus spontaneous labor
}

\author{
Salma Kousar Beigh*, Samar Mukhtar, Nighat Firdous, Fariha Amaan
}

Department of Obstetrics and Gynecology, Government Medical College Srinagar, Jammu and Kashmir, India

Received: 01 September 2021

Revised: 01 October 2021

Accepted: 04 October 2021

\section{*Correspondence:}

Dr. Salma Kousar Beigh,

E-mail: dr.salmabeigh@gmail.com

Copyright: (c) the author(s), publisher and licensee Medip Academy. This is an open-access article distributed under the terms of the Creative Commons Attribution Non-Commercial License, which permits unrestricted non-commercial use, distribution, and reproduction in any medium, provided the original work is properly cited.

\begin{abstract}
Background: Elective induction of labor is defined as an initiation of labor, either by mechanical or pharmacological means at a time earlier than nature regardless of a medical or obstetric indication. Objectives were to estimate the proportion of caesarean sections and vaginal deliveries and magnitude of maternal complications following elective induction and spontaneous labor.

Methods: The study entitled "comparison of caesarean section rate and maternal complications in elective induction versus spontaneous labor in LD Hospital, Kashmir" was a hospital based observational study, conducted in the Postgraduate Department of Obstetrics and Gynaecology, LallaDed Hospital of Government Medical College, Srinagar over a period of one and a half years.

Results: Women in induced labor group had slightly increased risk of caesarean section than those in spontaneous group. Fetal distress was the most common indication for caesarean section in both the groups. There was no difference in both groups regarding maternal complications such as perineal lacerations; postpartum hemorrhage (PPH); need for blood transfusions and post partum hospital stay.

Conclusions: Though induction of labor is associated with a slight increased risk of caesarean delivery, it is not related to other maternal complications. Therefore inductions are safe in hands of safe obstetricians.
\end{abstract}

Keywords: Caesarean section, Elective induction, Maternal complications, Spontaneous labour

\section{INTRODUCTION}

World Health Organization (WHO) defines 'normal birth' as spontaneous in onset, low risk at start of labor and remaining so throughout labor and delivery. The infant is born spontaneously in vertex position between 37 and 42 completed weeks of pregnancy and mother and infant are in good condition after birth. Currently most patients in Asia and also obstetricians prefer elective induction rather than spontaneous labor.

Elective induction of labor is defined as an initiation of labor, either by mechanical or pharmacological means at a time earlier than nature regardless of a medical or obstetric indication..$^{1-4}$ A caesarean section is usually performed after elective induction for following indicationsprolonged first stage of labor, fetal distress, failure to progress and intrapartum haemorrhage. Some adverse maternal outcomes have been associated with elective induction of labor. These include an increase in instrumental vaginal deliveries, greater need for epidural analgesia, postpartum haemorrhage, increased need for blood transfusion, longer hospital stays and higher hospital costs. ${ }^{5,6}$

\section{Induction of labour}

Labor induction is the initiation of uterine contractions prior to their spontaneous onset, leading to cervical dilatation and effacement and delivery of baby. ${ }^{7}$ Induction 
of labor has two important components, cervical ripening and stimulation of uterine contractions to achieve dilatation of cervix and delivery of the fetus. It is well recognized that the success of induction of labor, which ultimately aims at achieving vaginal delivery depends to a great extent on favourability of cervix. The likelihood of success is indicated by a number of perfectly recognisable findings which have been compiled as the modified Bishop's score comprising of dilatation and effacement of cervix, consistency and position of cervix and station of presenting part.

Table 1: Methods used for cervical ripening.

\begin{tabular}{|lll|}
\hline $\begin{array}{l}\text { Mechanical } \\
\text { methods }\end{array}$ & $\begin{array}{l}\text { Surgical } \\
\text { methods }\end{array}$ & $\begin{array}{l}\text { Medical } \\
\text { methods }\end{array}$ \\
\hline $\begin{array}{l}\text { Membrane } \\
\text { stripping }\end{array}$ & Amniotomy & Oxytocin \\
\hline $\begin{array}{l}\text { Mechanical } \\
\text { dilators }\end{array}$ & Prostaglandins \\
\hline $\begin{array}{l}\text { Hygroscopic } \\
\text { dilators }\end{array}$ & E2 (dinoprostone) \\
\hline Laminaria tents & E1 (misoprostol) \\
\hline Lamicel & $\begin{array}{l}\text { Progesterone } \\
\text { receptor } \\
\text { antagonist } \\
\text { (mifepristone) }\end{array}$ \\
\hline $\begin{array}{l}\text { Foley's balloon } \\
\text { catheter }\end{array}$ & $\begin{array}{l}\text { Nitric oxide } \\
\text { donors }\end{array}$ \\
\hline $\begin{array}{l}\text { Without extra- } \\
\text { amniotic saline } \\
\text { infusion }\end{array}$ & $\begin{array}{l}\text { Estrogen, } \\
\text { Relaxin, } \\
\text { Hyaluronic acid }\end{array}$ \\
\hline $\begin{array}{l}\text { With extra- } \\
\text { amniotic saline } \\
\text { infusion }\end{array}$ & \\
\hline
\end{tabular}

\section{Aims and objectives}

To estimate the proportion of caesarean sections and vaginal deliveries among elective induction and spontaneous labor groups. To estimate the magnitude of maternal complications following elective induction and spontaneous labor.

\section{METHODS}

\section{Study type}

The present study entitled "comparison of caesarean section rate and maternal complications in elective induction versus spontaneous labor in LD Hospital, Kashmir" was a hospital based prospective observational study,

\section{Study place}

Conducted in the Postgraduate Department of Obstetrics and Gynaecology, LallaDed Hospital of Government Medical College, Srinagar.

\section{Study duration}

The study took place over a period of one and a half years from March 2015 to September 2016.

\section{Selection criteria}

The patients included in the study were primigravidae to gravidae 3, aged between 20 to 35 years with term singleton pregnancy and cephalic presentation. The following patients were excluded from the study: previous LSCS or myomectomy, multiple pregnancy, breech or abnormal presentation, maternal medical disorders like $\mathrm{PIH}$, DM, cardiac diseases, cephalopelvic disproportion and maternal age $<20$ or $>35$ years.

\section{Statistical analysis}

Statistical software SPSS (version 20.0) was used to carry out the statistical analysis of data. Student's independent ttest was employed for parametric data and for nonparametric data chi-square test or Fishers exact test, whichever appropriate, was used. $\mathrm{P}$ value less than 0.05 was considered statistically significant. The sample size has been calculated on the basis of formula

$$
\begin{gathered}
\mathrm{n}=\frac{\mathrm{z}^{2} 1-\mathrm{a} / 2\left[\mathrm{P}_{1}\left(1-\mathrm{P}_{2}\right)+\mathrm{P}_{2}\left(1-\mathrm{P}_{2}\right)\right]}{\mathrm{d}^{2}} \\
\mathrm{n}=\frac{\mathrm{z}^{2} 1-\mathrm{a} / 2}{\mathrm{~d}^{2}}
\end{gathered}
$$

\section{Ethical clearance}

A meeting of Ethical Committee of Government Medical College Srinagar was held on 20 October 2015 in the meeting hall of Government Medical College Srinagar to discuss the ethical clearance of project "comparison of caesarean section rate and maternal complications in elective induction versus spontaneous labor". The meeting discussed threadbare ethical issues involved in the study and the committee unanimously decided to clear the research project.

\section{Methodology}

After obtaining the ethical clearance from the institutional ethical committee, this study was conducted in 200 term pregnant women being admitted for delivery in antenatal clinic of LallaDed Hospital, Government Medical College, Srinagar. A detailed history was taken and a detailed record of each patient was kept on proforma. Complete general and obstetrical examination; per abdomen: fundal height; lie; presentation and position were noted and fetal heart auscultated and per vaginum examination were done. Bishop score was determined by noting following factors: dilatation and effacement of cervix, position and consistency of cervix and station of head. Detailed ultrasonography was done to confirm the gestational age, 
placental localization, to rule out multiple pregnancy and congenital anomalies and amount of liquor.

The study population was divided into two groups by checking labor status to form:

1) electively induced group (100): induction was done in patients who met the following criterion: (i) term pregnancy, (ii) single live fetus in cephalic presentation. The elective induction group was counselled about the procedure of elective induction and consent was taken. Induction was done using dinoprostone gel. Procedure: a baseline CTG was done. Induction was done only in patients with a reactive CTG. Patient put in lithotomy position. Rate, rhythm and intensity of fetal heart sound noted. Under all aseptic precautions vaginal wall was retracted with sims speculum. Anterior lip of cervix was held with sponge holding forceps and dinoprostone gel $(0.5 \mathrm{mg})$ in a preloaded syringe with catheter was instilled into cervical canal beginning at internal os and gently withdrawing the catheter to external os as while continuously injecting the gel. The fetal heart sound was heard immediately after the procedure and the patient was asked to remain recumbent for about half an hour. Cervical scoring was repeated after six hours and reinstillation of dinoprostone gel was considered and if required, upto a maximum of three doses were instilled. Failure of induction was considered if cervix remained unfavourable after three doses.
2) Spontaneous labor group: this group included those women who were diagnosed as being in labor at admission. The criteria used to diagnose spontaneous labor were: regular painful uterine contractions together with either complete cervical effacement or presence of bag of fore-waters or onset of pain and regular uterine contractions every ten minutes or less with or without mucous bloody show.

Once the active phase of labor reached, the same intrapartum guidelines were followed in both groups. Progress of labor was monitored with regular abdominal and vaginal examinations. Oxytocin infusion was used in women already in active phase of labor with inadequate uterine contractions.

The outcomes of interest studied were mode of delivery (vaginal/caesarean), postpartum haemorrhage, perineal lacerations, need for blood transfusion, postpartum hospital stay ( $<7$ days or $>7$ days).

\section{RESULTS}

The age of patients ranged from 21-34 years in both groups with a mean age of 26.6 years in group 1 and a mean age of 26.8 years in group 2. There was no significant difference statistically with a p value of 0.629 (Table 2).

Table 2: Age and parity distribution of patients in two groups.

\begin{tabular}{|c|c|c|c|c|c|c|}
\hline & & \multicolumn{2}{|c|}{ Group 1} & \multicolumn{2}{|c|}{ Group 2} & \multirow{2}{*}{ P value } \\
\hline & & No. & $\%$ & No. & $\%$ & \\
\hline \multirow{4}{*}{ Age in years } & $20-24$ & 20 & 20 & 22 & 22 & \multirow{4}{*}{$0.629^{\#}$} \\
\hline & $25-29$ & 63 & 63 & 57 & 57 & \\
\hline & $30-34$ & 17 & 17 & 21 & 21 & \\
\hline & Mean \pm SD & $26.6=$ & & 26.8 & & \\
\hline \multirow{3}{*}{ Parity } & $20-24$ & 20 & 20 & 22 & 22 & \multirow{3}{*}{$0.629^{\#}$} \\
\hline & $25-29$ & 63 & 63 & 57 & 57 & \\
\hline & $30-34$ & 17 & 17 & 21 & 21 & \\
\hline
\end{tabular}

\#Statistically non-significant difference ( $\mathrm{p}$ value $>0.05$ )

Table 3: Comparison between two groups based on mode of delivery in total patients, in nulliparas and in multiparas.

\begin{tabular}{|c|c|c|c|c|c|c|c|}
\hline & \multicolumn{2}{|c|}{ Group 1 (induced) } & \multicolumn{2}{|c|}{ Group 2 (spontaneous) } & \multirow{2}{*}{ RR (95\% CI) } & \multirow{2}{*}{ P value } \\
\hline & & No. & $\%$ & No. & $\%$ & & \\
\hline \multirow{3}{*}{$\begin{array}{l}\text { Mode of } \\
\text { delivery in } \\
\text { total patients }\end{array}$} & Vaginal & 62 & 62 & 72 & 72 & 1.0 (Ref.) & \multirow{3}{*}{$\begin{array}{l}0.322 \\
\text { (NS) }\end{array}$} \\
\hline & Caesarean & 31 & 31 & 23 & 23 & $1.24(0.93-1.66)$ & \\
\hline & Instrumental & 7 & 7 & 5 & 5 & $1.26(0.76-2.10)$ & \\
\hline \multirow{3}{*}{$\begin{array}{l}\text { Mode of } \\
\text { delivery in } \\
\text { nulliparas }\end{array}$} & Vaginal & 35 & 53.8 & 36 & 61.0 & 1.0 (Ref.) & \multirow{3}{*}{$\begin{array}{l}0.702 \\
\text { (NS) }\end{array}$} \\
\hline & Caesarean & 24 & 36.9 & 19 & 32.2 & $1.36(0.91-2.04)$ & \\
\hline & Instrumental & 6 & 9.2 & 4 & 6.8 & $1.46(0.81-2.64)$ & \\
\hline \multirow{3}{*}{$\begin{array}{l}\text { Mode of } \\
\text { delivery in } \\
\text { multiparas }\end{array}$} & Vaginal & 27 & 77.1 & 36 & 87.8 & 1.0 (Ref.) & \multirow{3}{*}{$\begin{array}{l}0.440 \\
(\mathrm{NS})\end{array}$} \\
\hline & Caesarean & 7 & 20.0 & 4 & 9.8 & $1.49(0.87-2.52)$ & \\
\hline & Instrumental & 1 & 2.9 & 1 & 2.4 & $1.17(0.28-4.80)$ & \\
\hline
\end{tabular}

$\mathrm{S}=$ Significant; NS = Non-significant; RR = Relative risk; $\mathrm{p}$ value $>0.05$ (NS) 
Table 4: Comparison between two groups based on indications for LSCS.

\begin{tabular}{|lllll|} 
& \multicolumn{2}{l}{ Group 1 (induced) } & \multicolumn{2}{l|}{ Group 2 (spontaneous) } \\
\cline { 2 - 5 } & No. & \% & No. & \% \\
\hline Fetal distress & 24 & 77.4 & 18 & 78.2 \\
\hline NPOL & 3 & 9.6 & 4 & 17.4 \\
\hline NDOH & 2 & 6.5 & 1 & 4.4 \\
\hline Failure of induction & 2 & 6.5 & 0 & 0.532 \\
\hline
\end{tabular}

\#Statistically non-significant difference (p value $<0.05$ )

Table 5: Comparison between two groups based on postpartum haemorrhage (PPH) and blood transfusion.

\begin{tabular}{|c|c|c|c|c|c|c|c|}
\hline & & \multicolumn{2}{|c|}{ Group 1} & \multicolumn{2}{|c|}{ Group 2} & \multirow{2}{*}{$\mathbf{R R}(95 \%$ CI $)$} & \multirow{2}{*}{$P$ value } \\
\hline & & No. & $\%$ & No. & $\%$ & & \\
\hline \multirow{3}{*}{ PPH } & No hemorrhage & 93 & 93 & 95 & 95 & 1.0 (Ref.) & \multirow{3}{*}{0.574} \\
\hline & Atonic & 6 & 6 & 5 & 5 & $1.10(0.63-1.93)$ & \\
\hline & Traumatic & 1 & 1 & 0 & 0 & $2.02(1.75-2.34)$ & \\
\hline \multirow{2}{*}{$\begin{array}{l}\text { Blood } \\
\text { transfusion }\end{array}$} & Yes & 0 & 0 & 2 & 2 & 0 & \multirow{2}{*}{0.498 (NS) } \\
\hline & No & 100 & 100 & 98 & 98 & 1.0 (Ref.) & \\
\hline
\end{tabular}

\#Statistically non-significant difference ( $\mathrm{p}$ value>0.05); RR: Relative risk

Women in group 2 were comparably of higher parity than in group 1, but the difference was not statistically significant (Table 2).

As is evident from the above Table 3 the percentage of patients delivered by cesarean section was $31 \%$ in induced group and $23 \%$ in spontaneous group. The percentage of cesarean deliveries among induced nullipara was $36.9 \%$ and in spontaneous nullipara group (group 2) was $32.2 \%$. Percentage of cesarean deliveries among multiparous women in induced group was $20 \%$ and among spontaneous group was $9.8 \%$.

Atonic PPH was seen in $6 \%$ of cases and traumatic in $1 \%$ of cases in group 1 whereas the percentage of atonic haemorrhage was 5\% and traumatic was $0 \%$ in group 2 . Blood transfusion was needed in $2(2 \%)$ patients in group 2 and none in group 1.

\section{DISCUSSION}

Labor induction is the initiation of uterine contractions prior to their spontaneous onset, leading to cervical dilatation and effacement and delivery of baby. A general concept is that induction is associated with increased complications as compared to spontaneous labor. This concept forms the basis for the need for this study.

Considering parity with mode of onset of labor, there was comparably higher parity in spontaneous labor group. 59 $(59 \%)$ nulliparous women had spontaneous labor whereas $65(65 \%)$ nulliparous women were induced. Of the multiparous women, $41(41 \%)$ had spontaneous labor and $35(35 \%)$ were induced. These results are in comparison to studies done by Heffner et al in which $30 \%$ of nulliparas had induced labor and 27\% multiparas had induced labor; and Caroline et al in which $47.25 \%$ of nulliparas had spontaneous labor whereas $52.74 \%$ nulliparas were induced. ${ }^{11,12}$ Of the multiparas $59.76 \%$ had spontaneous labor and $40.26 \%$ were induced.

Regarding the mode of delivery, this study demonstrates that women in spontaneous labor group had high chance of vaginal delivery than those in induced group. Induced nulliparas had $36.9 \%$ cesarean delivery rate, compared with $32.2 \%$ among spontaneous labor group. The cesarean delivery rate was $20.0 \%$ in induced multiparas compared with $9.8 \%$ in spontaneous group. Our finding of modest increase in cesarean delivery among women with induced labor is in concurrence with results of following studies: Caroline et al in which induced nulliparas had $29.15 \%$ cesarean section rate, compared with $16.6 \%$ among spontaneous labor group. ${ }^{11}$ Taofeek et al in which caesarean section rate was $20.6 \%$ in spontaneous labor group and $35.3 \%$ in induced labor group. ${ }^{13}$

Indications for caesarean delivery were not statistically different among two groups. Fetal distress was the most common indication being $77.4 \%$ in induced group and $78.2 \%$ in spontaneous labor group followed by nonprogression of labor being $9.6 \%$ in induced and $17.39 \%$ in spontaneous group. This is in concurrence with study done by Caroline et al. ${ }^{11}$ However this is in contrast to the study done by Johnson et al where failure to progress was the most common indication followed by fetal distress. ${ }^{14}$ However the indications for caesarean section did not differ significantly between two groups.

The third stage complications like PPH was seen in $7 \%$ cases of induced group and 5\% cases of spontaneous labor group with a $\mathrm{p}$ value of 0.774 which is not statistically significant. Elective induction group was not associated with increased risk of perineal laceration or lengthened hospital stay or greater need for blood transfusion. This is 
concurrent with the results of Guerra et al according to which elective induction of labor is not associated with increased risk of perineal lacerations or postpartum hemorrhage; lengthened hospital stay or a greater need for blood transfusion. ${ }^{15}$ Our findings are also comparable with the study done by Macer et al who found no difference between the two groups with respect to intrapartum or postpartum maternal complications. ${ }^{16}$

As the study had a short follow up done during hospital stay, long term complications like cervical and bladder descent were not assessed. Studies doing long term follow up will be needed to assess such complications.

\section{CONCLUSION}

From this study we concluded that the elective induction of labor is associated with slight increased risk of caesarean section though the difference was statistically insignificant. The indications for operative delivery did not change with the mode of induction i.e. induction did not increase risk of fetal distress. There was no difference in both groups regarding maternal complications such as perineal lacerations; PPH; need for blood transfusions and postpartum hospital stay. So inductions are safe in hands of safe obstetricians. Obstetricians can set delivery time during daytime of a working day when related teams such as obstetrician staff, anaesthetists, pediatricians and nursing teams are more likely to be available.

\section{Funding: No funding sources}

Conflict of interest: None declared

Ethical approval: The study was approved by the Institutional Ethics Committee

\section{REFERENCES}

1. Smith PL, Nagourney AB, McLean HF, Usher HR. Hazards and benefits of elective induction of labor. Am J Obstet Gynecol. 1984;148:579-85.

2. Vierhout ME, Out JJ, Wallenburg HC. Elective induction of labor: a prospective clinical study, I: obstetric and neonatal effects. J Perinat Med. 1985;13:155-62.

3. Macer AJ, Macer an LC, Chan SI. Elective induction versus spontaneous labor- a retrospective study of complications and outcome. Am J Obstet Gynecol. 1992;166:1690-97.

4. Jackson M, Regan C. Elective induction of labor. Clin Obstet Gynecol. 1997;40:496-509.

5. Glantz JC. Elective induction versus spontaneous labor associations and outcome. J Reprod Med. 2005;50(4):235-40.
6. Dublin S, Lydon-Rochelle M, Kaplan RC, Watts DH, Critchiow CW. Maternal and neonatal outcomes after induction of labor without an identified indication. Am J Obstet Gynecol. 2000;182:986-94.

7. Leveno C, Hauth B, Spong R. Normal labor and delivery. In: Cunningham FG, Lenovo KJ, Bloom SL, Dashe JS, Hoffman BL, Casey BM, et al, eds. Williams Obstetrics. 23rd edition. McGraw Hill Publication; 2010:374.

8. Mitchell MD, Flent AP, Bibby J, Brunt J. Rapid increase in plasma $\mathrm{PG}$ concentration after vaginal examination and amniotomy. $\mathrm{Br}$ Med J. 1977;2(6096):1183-5.

9. ACOG Committee. ACOG Committe Opinion. New US Food and Drug Administration labeling on cytotec (misoprostol) use and pregnancy. Number 283, May 2003. Int J Gynaecol Obstet. 2003;82(1):137-8.

10. Goel K, Gedem J. Induction of labor- a review. Indian J Clin Pract. 2014;24(11).

11. Caroline A. Induced versus spontaneous labor: comparison of outcome of delivery. Dissertation submitted to Rajiv Gandhi University of Health Sciences, Karnataka, Bangalore. 2008.

12. Heffner LJ, Elkin E, Fretts RC. Impact of labor induction, gestational age, and maternal age on cesarean delivery rates. Obstet Gynecol. 2003;102(2):287-93.

13. Orji EO, Olabode TO. Comparative study of labor progress and delivery outcome among induced versus spontaneous labor in nulliparous women using modified WHO partograph. Nepal J Obstet Gynecol. 2008;3(1):24-8.

14. Johnson DP, Davis NR, Brown AJ. Risk of caesarean delivery after induction at term in nulliparous women with an unfavorable cervix. Am J Obstet Gynecol 2003; 188:1565-72.

15. Guerra GV, Cecatti JG, Souza JP, Faúndes A, Morais SS, Gülmezoglu AM, et al. Elective induction versus spontaneous labour in Latin America. Bull World Health Organ. 2011;89:657-65.

16. Macer AJ, Macer LC, Chan SI. Elective induction versus spontaneous labor- a retrospective study of complications and outcome. Am J Obstet Gynecol. 1992;166:1690-7.

Cite this article as: Beigh SK, Mukhtar S, Firdous $\mathrm{N}$, Amaan F. Comparison of caesarean section rate and maternal complications in elective induction versus spontaneous labor. Int J Reprod Contracept Obstet Gynecol 2021;10:4249-53. 